\title{
AEG EESTI MURRETES
}

\author{
EVA VELSKER
}

Annotatsioon. Artiklis uuritakse sõna aeg kasutust eesti murretes, analüüsitav materjal pärineb eesti murrete korpusest. Vaadeldakse piirkondade kaupa käändevormide esinemist, tuuakse esile võimalikud grammatiseerumis- ja leksikaliseerumisnähud. Analüüsitud keelematerjali põhjal leidis kinnitust oletus, et piirkonniti on kasutus erinev, ilmnesid kindla morfosüntaktilise struktuuri ja tähendusega seotud kasutusmustrid.

Võtmesõnad: eesti murded, varieerumine, leksikaliseerumine, grammatiseerumine

\section{Sissejuhatus}

Aja väljendamine keeles on uurijaid ikka köitnud, omaette huvitav on sõna aeg isegi, seda eriti murretes, kus selle kasutuses on märgatavat varieerumist. Murrete kõrvutava uurimise on muutnud hõlpsamaks elektrooniliselt kättesaadavad tekstid eesti murrete korpuses1, mida on koostatud alates 1998. aastast Tartu Ülikooli ja Eesti Keele Instituudi koostöös. Morfoloogiliselt märgendatud korpus aitab uurijal analüüsitavaid keelendeid kergesti leida. Samas on murdekorpuse korduvaks probleemiks sõnaliikide määramine. Murdekeele varieeruvus, toimuvad muutused, grammatiseerumine ja leksikaliseerumine teevad vormide interpreteerimise mõnelgi juhul keerukaks. Üks tüüpilisi probleemkohti on ajamääruslike väljendite analüüs. Kui mitme sõna puhul tuleb otsustada, kas tegu on substantiivi käändevormi või adverbiga (nt ajaväljendid: kas omiku on käändevorm (singulari genitiiv vormist omik) või juba ajaadverb), siis sõna aeg seab

\footnotetext{
1 http://www.murre.ut.ee/murdekorpus. Korpus koosneb murdelindistustest, foneetilises transkriptsioonis murdetekstidest, lihtsustatud transkriptsioonis murdetekstidest, morfoloogiliselt märgendatud murdetekstidest ja andmebaasist, mis sisaldab infot keelejuhtide ja lindistuste kohta. Lindistused pärinevad põhiosas 1960.-1970. aastatest, tekstid on autentsed, hoolikalt valitud ja litereeritud. (Korpusest lähemalt vt nt Lindström jt 2009.)
} 
uurija ette kolmandagi küsimuse: kas tegu võib olla mõne vormi kaassõnastumisega. Järgnevalt antaksegi ülevaade sõna aeg kasutusest eesti murretes, püüdes välja selgitada piirkondlikke erinevusi ja võimalikke tähendusega seotud vormimuutusi. Artikli eesmärk on uurida sõna aeg kasutuse dünaamikat murdekorpuses leiduva materjali põhjal, osutada piirialadele substantiivi käändevormi, adpositsiooni ja adverbi vahel ning välja tuua võimalikke grammatiseerumis- ja leksikaliseerumistendentse. Korpusel põhinev uurimine aitab välja selgitada kasutusmustreid, ehkki varju võivad jääda keelendid, mida on käsitletud varasemates uurimustes (nii ei tulnud ka aeg-sõna puhul murdekorpuses esile kõiki murdesõnaraamatus ja -ülevaadetes esitatud vorme ega fraase), seesugune lähenemine võimaldab paremini uurida keelekasutuse dünaamikat ning leida üldisemaid tendentse vormikasutuses. Käesoleva uurimuse materjal ongi kogutud eesti murrete korpusest. Murdekorpuse näited on esitatud lihtsustatud transkriptsioonis, muude allikate näited aga vastava allika transkriptsioonis. Esmases ülevaates on lähtutud murdekorpuse märgendusest, analüüsiosa põhineb artikli autori liigitusel.

\section{Aeg grammatiseerumis- ja leksikaliseerumisprotsessis}

Sõnaliikide probleemiga, sealhulgas ka substantiivide, adpositsioonide ja adverbide vahekorraga on tegeldud nii mitmeski uurimuses. Peale kirjakeele on käsitletud sõnaliigitust murretes (Lindström jt 2006) ning vanas kirjakeeles (Habicht jt 2011). Mõlemal juhul teeb analüüsimise keerukaks keele arhailisus, murdekeele puhul aga suurem varieeruvus ning muutuvus, grammatiseerumine ja leksikaliseerumine. Grammatiseerumisleksikonist võib leida näiteid, kus sõnast aeg on arenenud ajaseost märkiv alistav sidend (tähendusega 'kui', 'kuni', 'sellal kui') - sellisel juhul on tegu protsessiga, kus areda semantilise omadusega substantiivist tekib grammatiline marker, mis seda omadust esile tõstab (Heine, Kuteva 2002: 298-299). Eesti keele puhul võiks olla võimalik sõna aeg mõne käändevormi (adessiivi, partitiivi) kaassõnastumine, teisalt ka sagedamini esineva sõnaühendi iseseisvumine (nt sell aal, sell=aal) ${ }^{2}$. Eesti kaassõnad on suures osas tekkinud substantiivi käändevormide iseseisvumise tulemusel, samasugune protsess jätkub ka nüüdisajal ja mõnikord on üsna

2 Murdekorpuses kasutatud lihtsustatud transkriptsiooni kohta vt http://www.murre. ut.ee/murdekorpuse-otsing/ (pikemalt Lindström 2009: 7-8). 
keeruline eristada postpositsiooni substantiivist, samamoodi on hägune ka piir adpositsiooni ja adverbi vahel. Sõna aeg vormide kasutus ilmestab seda päris hästi. Vormi ajal on näiteks vanemates allikates peetud kaassõnaks, Ferdinand Johann Wiedemanni grammatikas on esitatud postpositsioonidena nii ajal kui ka aegu, samas märgib Wiedemann, et hulgaliselt esineb ka noomeneid, mille puhul postpositsioonidena käsitatavaid käändevorme saab tõlgendada ka noomenina (Wiedemann 2011: 587). Aeg-sõna vorme on käsitletud mõnevõrra erinevalt ka sõnaraamatutes: nii on kirjakeele sõnaraamatutes (õigekeelsussõnaraamatus ja seletussõnaraamatus) aegu esitatud omaette märksõnana, märksõnalt ajal on viidatud aga märksõnale aeg. Väikeses vormisõnastikus on kaassõnaks märgitud nii aegu kui ka ajal, samuti kestust näitav aega (VVS: 3, 6). Murdesõnaraamatus on eraldi märksõnadena esitatud aega (tähenduses 'ajal, paiku'), aegu, samuti inessiivikujuline aegas ning muudki kujud (aegus, aegis, aigidõ), mida otseselt käändevormiga seostada ei saa. Adessiivsed vormid (aal, ajal, aeal) on seevastu paigutatud märksõna aeg alla, seega võib eeldada, et neid on käsitatud substantiivivormidena.

Sõna aeg puhul võib muidugi mõneti küsitavaks pidada, kas üldse on võimalik rääkida sõna(vormi) leksikaliseerumisest või grammatiseerumisest - ühelt poolt on tegu täistähendusliku sõnaga, mille puhul ilmselt ei saa otseselt rääkida ,leksikaalsemaks muutumisest”, nagu leksikaliseerumist enamasti defineeritakse (vt nt Brinton, Traugott 2005). Ent skalaarse käsitluse järgi võib siiski sõnavormi iseseisvumist ja morfeemipiiride kadumist (seega ka adverbistumist, sõnavormi kujunemist iseseisvaks määrsõnaks) teatava astme leksikaliseerumiseks pidada. ${ }^{3}$ Teisalt on sõna aeg tähendus abstraktsevõitu, grammatiseerumine eeldab aga semantilist pleekumist. Nii üldise tähenduse puhul võib kahelda, kas tähenduse üldisemaks muutumine on võimalik. Näidetele toetudes võib seda siiski oletada: mõnikord näib sõna aeg mõni vorm toimivat pigem abisõnana, põhitähendust kannab fraasis atribuudina vormistatud substantiiv.

Leksikaliseerumisest ja selle vahekorrast grammatiseerumisega vt lähemalt Velsker 2010 . 


\section{Sõna aeg sagedasematest vormidest}

2009. aastal ilmunud artiklis (Lindström jt 2009) vaadeldi eesti murrete sagedasemate substantiivide kõige sagedasemaid käändevorme ning püüti leida sagedase kasutamise põhjusi, eelkõige pöörates tähelepanu võimalikele adverbistumis- ja kaassõnastumisjuhtumitele. 100 sagedasema substantiivi hulgas oli mitu ajasõna (aasta, hommik jm); kõigi sõnade hulgas oli teisel kohal sõna $a e g$, mis muudest ajasõnadest eristus selle poolest, et kõige rohkem esines singulari adessiivi vorme $(34,8 \%$, järgnesid singulari nominatiiv 22,1\% ja partitiiv 20,8\%). Leksikaalse kasutuse kõrval oletati ka kaassõnastumistendentsi, millele võiks viidata adessiivivormide rohkus, teisalt ilmnes juba põgusal vaatlusel, et väga rohkesti esineb mõningaid ühendeid (nt sel aal), mis omakorda võib osutada sõnaühendi kinnistumisele ja (ase)määrsõnastumisele. Sageduse osa on oluline nii grammatiseerumisel kui ka leksikaliseerumisel - mida grammatiseerunum on vorm, seda sagedamini see esineb (Hopper, Traugott 2003: 113). Teisalt võib sage kasutus ise põhjustada sõnavormi eraldumist paradigmast ja muutumist iseseisvaks üksuseks kõneleja leksikonis (Bybee 2007: 13), see võib olla konstruktsiooni säilitava mõjuga ning ühe tegurina aidata kaasa selle autonoomsuse suurenemisele (Bybee 2010: 50).

2010. aasta septembris olid morfoloogiliselt märgendatud korpuses tehtud otsingu tulemused suuresti samasugused ja osutasid samasuguseid tendentse: 1235 käändevormi hulgas kolm kõige sagedamini kasutatud käänet on singulari adessiiv, nominatiiv ja partitiiv. Tabelis 1 on esitatud sagedasemad käändevormid murdekorpuse märgendusest lähtudes.

Tabel 1. Sõna aeg sagedasemad käändevormid eesti murrete korpuses

\begin{tabular}{|l|c|c|}
\hline Kääne & Vorme & Osakaal \% \\
\hline Singulari adessiiv & 458 & 37 \\
\hline Singulari nominatiiv & 296 & 24 \\
\hline Singulari partitiiv & 244 & 20 \\
\hline Singulari genitiiv & 91 & 7 \\
\hline Singulari inessiiv & 54 & 4 \\
\hline
\end{tabular}

Kas aga murderühmiti ja murdeti on pilt ühesugune? Juba esialgne statistika toob ilmsiks ühe selge erinevuse: lõunaeesti murretes on adessiivi 
osakaal väiksem kui põhjaeesti ja kirderannikumurretes (seisuga 23. september 2010). Tabelis 2 on esitatud sõna aeg sagedasemad käändevormid murderühmiti.

Tabel 2. Sõna aeg sagedasemad käändevormid eesti murretes

\begin{tabular}{|l|c|c|c|c|c|c|}
\hline & \multicolumn{2}{|c|}{ Põhja-Eesti } & \multicolumn{2}{c|}{ Lõuna-Eesti } & \multicolumn{2}{c|}{ Kirderannik } \\
\hline Kääne & Vorme & Osakaal \% & Vorme & Osakaal \% & Vorme & Osakaal \% \\
\hline Singulari adessiiv & 320 & 38,3 & 64 & 25 & 74 & 44,8 \\
\hline $\begin{array}{l}\text { Singulari } \\
\text { nominatiiv }\end{array}$ & 190 & 22,7 & 70 & 27,3 & 36 & 21,8 \\
\hline Singulari partitiiv & 158 & 18,9 & 64 & 25 & 22 & 13,3 \\
\hline Singulari genitiiv & 44 & 5,3 & 29 & 11 & 18 & 11 \\
\hline $\begin{array}{l}\text { Muude käände- } \\
\text { vormidega kokku }\end{array}$ & 836 & & 256 & & 165 & \\
\hline
\end{tabular}

Inessiiv on sagedasemate käänete hulgas just nimelt põhjaeestilise kasutuse tõttu: seal ongi see sageduselt viiendal kohal (52 vormi, 6,2\%) LõunaEesti tekstides inessiivivormi ei leidunudki. Ka kirderanniku murderühma tekstides esineb singulari inessiiv vaid kaks korda, viiendal kohal on translatiiv nelja näitega $(2,4 \%)$. Lõuna-Eesti murretes on viiendal kohal pluurali partitiiv (13 vormi, 5,1\%), tegelikult on kõikidel juhtudel aga tegemist ilmselt märgendamiseksimusega ja need peaksid olema singulari partitiivi vormid ('aega, ’aigo).

Leksikaalsuse ja grammatilisuse hägusest piirialast annavad muu hulgas märku märgendusraskused. Näiteks on põhjaeesti murdetekstides märksõna $a e g u$ või aeg all postpositsiooniks märgendatud 43 vormi: aeg, ao, ‘aega (aega), ’aegas (’ãogas), ‘aeges (’ã̃gõs), ’aegu (aegu, ‘ã̃gu), 'aegus. Märksõnaga ajal on postpositsiooniks paigutatud Põhja-Eesti tekstides 32 vormi ('aegas, 'aegus, aal, aeal (ajal)). Lõuna-Eesti tekstides on postpositsiooniks märgitud vorme veelgi enam: märksõnaga aegu on postpositsiooniks märgitud 134 vormi ('aiga, aiga, ‘aigu, aigu, ‘aigo, aigo). Märksõna ajal annab veel 7 otsinguvastust ( 'aigu, aal, aeal). Kirderanniku murderühmas on postpositsioonina märksõna ajal all 15 vormi, 5 vormi (aega, aigul, ajal, aeal, aegu) on postpositsioonina paigutatud märksõnade $a e g u$ või $a e g$ alla. Sageli ei olegi võimalik sõnaliigilise kuuluvuse üle üheselt otsustada, küll aga on oluline ühtsus märgenduspõhimõtetes. 
Niisiis toob juba üsna põgus ülevaade ilmsiks nii mõnegi probleemkoha, kus vormi on teatud põhjustel võimalik tõlgendada erinevalt. Kui võtta arvesse ka postpositsiooniks märgendatud partitiivi- ja adessiivikujulised vormid, siis tulevad murderühmade erinevused veelgi selgemalt ilmsiks, kõige aredamalt eristub siis Lõuna-Eesti murderühm, kus erinevalt Põhja-Eesti rühmast on kõige suurem osakaal partitiivikujulistel vormidel. Kirderannikurühmas on omakorda kõige suurem adessiivikujuliste vormide osakaal, nagu ka Põhja-Eesti murderühmas, kus aga selle kõrval näib olevat kasutusel muidki väljendusvõimalusi. Kui arvestada käändevormide hulka ka samakujulised kaassõnaks märgendatud vormid, toob see murderühmade erinevused veelgi rohkem esile.

Et leida eri käändevormide erisuguse kasutussageduse põhjusi, tuleb seega vaadata vorme murrete kaupa põhjalikumalt ja ühtlasi selgitada, kas sagedamini esinevate vormide puhul võib olla tegemist grammatiseerumistendentsiga (keeleüksus kaotab leksikaalset tähendust ja muutub grammatilisemaks, hakkab kandma eelkõige grammatilist tähendust) ja kas teisalt võib täheldada sõnaühendi kujunemist adverbiks.

\section{Sõna aeg vormid eesti murdealal}

Järgnevalt vaadeldakse lähemalt sõna aeg kasutust eesti murretes eesti murrete korpuse põhjal. Materjaliks on peale morfoloogiliselt märgendatud tekstide ka märgendamata (lihtsustatud transkriptsioonis) tekstid, kust on näiteid juurde otsitud. Näited on rühmitatud käsitsi, kuna seni ei ole võimalik automaatselt sorteerida konteksti (nt eelneva sõna järgi). Eespool olid esitatud täpsemad arvud morfoloogiliselt märgendatud korpuse andmetele tuginedes, edaspidi on osutatud kasutustendentsidele üldisemalt, seetõttu ei pruugi toodud arvandmed varasema statistikaga kattuda. Analüüsitud materjali on kokkuvõttes rohkem kui morfoloogiliselt märgendatud korpuses. Vormide analüüsimisel ei lähtuta edaspidi korpuse märgendusest, vaid vaadatakse esinemist vormi kaupa konkreetses keelelises ümbruses; kõiki näiteid on selle uurimuse tarvis uuesti analüüsitud. Kokku oli uuritud materjalis 1899 vormi, neist ajamäärusena kasutatud 1509, toimumisaega on väljendatud 1256 korral.

Sõna aeg esineb lauses sageli määrusena, sellele viitab adessiivivormide suur hulk. Eesti keeles võivad aga ajamäärusena esineda ka objektikäänded, seejuures esineb murdekorpuses rohkesti partitiivseid ja 
nominatiivseid vorme. Niisiis vajaks selgitamist näiteks seegi, kas murdeti on partitiivsete vormide rohkus põhjustatud eri teguritest.

EKG (77-86) jagab ajamäärused nelja rühma: 1) toimumisaega näitavad määrused, 2) ajapiiri näitavad määrused, c) kestust näitavad ajamäärused, d) kordust näitavad ajamäärused. Lehte Rannut (1960) on ajamääruse tähendusfunktsioone eritledes olnud detailsem ja toonud välja järgmised rühmad: 1) tegevus- või esinemisaeg, 2) ajapiir, 3) töö- või tasunormile vastav ajahulk, 4) kordumine, 5) kestus, 6) ajaline lõpp, 7) sagedus, 8) ajaline pidevus. Ühtlasi on ta eristanud veel mitmesuguseid alamtähendusi. Kõiki neid tähendusrühmi saab samas hõlmata ka EKG liigitusega, mis on aluseks ka siinses artiklis. Käesoleva töö seisukohalt on oluline märkida, et toimumisaja all ei mõelda mitte ainult tegevuse toimumist, tegu võib olla ka seisundiga või üleüldse mingi ajajärgule tüüpilise nähtusega. Omaette huvitav küsimus on muidugi vormi ja semantika vahekord, mida see artikkel puudutab vaid riivamisi, keskendudes eelkõige morfosüntaksile.

Kõige sagedamini väljendavad uuritud materjalis sõna aeg sisaldavad fraasid toimumisaega, aga palju esineb ka kestust näitavaid fraase. Kestust (kui kaua?) on väljendatud murretes üsna ühtmoodi: hulga-, mõõdusõna vms + partitiiv (ulga aega); selle kõrval on võimalik ka nominatiivi kasutus kirderannikumurretes. Kestust väljendavad ka nominatiivsed $e l u+a e g, k o g u$ aeg vms. Muud tähendusrühmad jäävad marginaalseks, nende väljendamine on enamasti piiratud kindla vormiga ja varieerumist materjalis ei ilmne. Nii näiteks väljendab ajalist lõpp-piiri terminatiiv (seni aani), ajalist algust elatiiv (sellest ajast), korduvust on võimalik märkida pluurali nominatiiviga. Need tähendusrühmad jäävad praegu vaatluse alt välja, keskendutakse vormidele, mis võivad näidata toimumis- ja esinemisaega ning mis on ühtlasi kõige sagedamini esinevad käändevormid (singulari nominatiiv, genitiiv, partitiiv, inessiiv, adessiiv ning kaassõnaline $(e g u)^{4}$. Toimumisaega väljendavates ajamäärustes ilmneb ka kõige suurem variatiivsus.

${ }^{4}$ Siinse artikli lähenemine on sünkroonne, mistõttu on näiteks partitiivseks loetud sellele vastavad kujud (millest osa on varem peetud essiivist lähtuvaks); analüüsis on siiski osutatud võimalikule paradigmast lahknemisele ja esinemisele kaassõnana. 


\subsection{Põhjaeesti murded}

\subsubsection{Saarte murre}

Saarte murdes (nagu ka läänemurdes, vt 4.1.2) torkab silma ajaväljendite mitmekesisus. Toimumisaega on kõige sagedamini väljendatud adessiiviga (124 näidet), ent selle kõrval on kasutatud ka muid vorme: partitiivi, nominatiivi, inessiivi; kaassõnastunud vormi aegu, ühendeid kaassõnadega sees ja peal.

Analüüsitud näidete põhjal võib väita, et vormivalik sõltub sõna $a e g$ laiendava täiendi sõnaliigist (kas tegu on adjektiiv- või genitiivatribuudiga). Adessiiv esineb koos ühilduva täiendiga (adjektiivatribuudiga): adjektiiviga (1-4) või pronoomeniga (5).

(1) Muh: sie pannasse seda+visi ${ }^{5}$ et (.) et vanal aal 'pandi 'ikka seda=visi et `sõukke sur puu püör 'pandi `ette (.)

(2) Käi: tead ühe+gorra oli need inimest kehvamad (.) 'nüitsel aeal inimest nii `rikkad=et nüid nüid tarvidada `seuseid `asju änam

(3) Jäm: aga vanade meestele pole ju='linnas `lastud 'uhtuda niid viimasel aal `lasti `riidid `ikka `uhtuda ’linnas (.)

(4) Khk: miss=see 'laidu elu se=suisel aeal onn äga (.) sügise (...) sügise kui=ta akkab `jääga (.) saa=p saa `välja `miskid `moodi

(5) Muh: see siiss tõi (.) vihu `õlgi `sõnna asemele (.) muud `asja=ss ole sell=aal (.) ja noorik ladus siiss kõik oma (.) aseme 'riided selle käli käe 'peale

Üle kolmandikul juhtudel (52 näidet) esineb aal või aeal koos pronoomeniga see (5). Kolmandikus näidetes (43 juhtu) on aeg kombineeritud adjektiiviga, sealjuures ei ole omadussõnade valik väga suur: tüüpilised on sõnaühendid vanal ajal, nü̈̈dsel ajal, viimasel ajal, lisaks adjektiivi abil väljendatud aastaajad (suisel aeal).

Adessiivsena võib esineda ka määrus siis, kui täiendiks on substantiiv (6) või personaalpronoomen, ent neid esineb siiski vähem kui inessiivivõi partitiivikujulisi vorme.

(6) Mus: see oli siss see (...) viletsuse aeg ett es ole (.) söa aeal 'kuskilt ‘miskit `saaea (...) nönda=t `meitte vana käis Aap+salust öli `toomas (...)

\footnotetext{
${ }^{5}$ Plussmärk tähistab liitsõna piiri.
} 
Saarte murdes torkab silma ka suhteliselt palju (12 näidet) analüütilisi väljendeid (genitiiv + sees) (7-9).

(7) Khk: ema=ja siss üheksa='aastane tüdruk se=samma se (Küngu) tüdruk ning nee jähid kahegesti `sisse ja=siiss selle aja sihes ema Emmi ema oli ära surnd ning tüdruk oli üheksa `aastane tüdruk oli jälle

(8) Muh: maa mäletta ju `selle aa kut kui `iidlased köisid sii `müimas tõid puu=kaosid minu määletse aa sees onn neid veel oln kui mina 'ikka `väikke `olli (...) saarel siin siis ise

(9) Jäm: nee olid moo aea=sees meeste riijetteks (...) no=siis 'kangas sai nendele kueuttud kaa (...)

Tegu on esialgu siiski suuresti subjektiivse muljega: samalaadseid kaassõnalisi väljendeid (genitiiv + sees) leiab mujaltki (ei leidunud vaid kirdemurdes ja Tartu murdes, kõigist teistest leidus korpuses üks või kaks näidet), põhjalikuma järelduse jaoks ei ole praegu piisavalt materjali. Küll tuli aga ainult saarte murdes esile kaassõnaga peal moodustatud ajamäärus (10). (Lehte Rannuti andmetel (1960: 73) esineb konstruktsioon ,genitiiv + peal" ainult rannikumurdes, murdekorpuse andmestikus aga kirderannikumurrete näiteid ei leidunud.)

(10) Jäm: mee olime Seppal pulmal nohh see oli niid moo aea pääl uuwema aea pääl $(. .$.

Partitiivivormide suur osakaal (70 näidet) on seletatav sõna aeg esinemisega kvantorifraasi koosseisus (natuke aega) ning püsiühendi osana (aega saama jms). Ligi veerandi murdekorpusest leitud näidete puhul on aga tegu toimumisaega näitava ajamäärusega (genitiiv + ‘aega), mida võib pidada kaassõnastunud vormiks.

(11) Khk: `sönna sammase nukki pääle jähi `kinni ’jooskes `sisse selle+bärast neid onn sii kala=püi püije `aega 'öösse onn onn keige ullem kui neid sedasi `öösse `käimas onn et=sa nüid ülal meres

(12) Mus: mis `küüttis siis 'käidi venelastel `küittis selle söa `aega pole ’küittis käind vähe sai `käidud

Võimalik, et partitiivi kasutamist selles tähenduses toetab paralleelne tugevaastmeline inessiiv (31 näidet), mida kasutatakse samuti genitiivatribuudiga (13-14). 
(13) Muh: ei nee=ss tee muud medagid kui nee joo `jälle `ollid pulma `aegas sääl lava taga $=$ ja mõegad `ollid käe $=$ ja ja siis torgatti nee mõegad `sõnna

(14) Khn: siis Kihnu laõvad vädäsid kõik `sjõnna 'Vindavi kive (...) sedä 'tehti tsaari=`ã̃gas (...) tsaari=`ãogu oli se (...)

Kõige sagedamini esinebki omastavas käändes substantiivi või pronoomeni järel inessiiv (24 näidet). Nii partitiivne `aega kui ka inessiivne `aegas (Khn `aõgas) esinevad toimumisaega väljendades genitiivatribuudiga (substantiiviga või personaalpronoomeniga), mõlemaid võib pidada kaassõnastunud vormideks. Lisaks on kasutatud ka vormi `aegu, adessiivikujuline vorm esineb valdavalt koos ühilduva täiendiga.

Toimumisaega väljendavates fraasides on seega valdav tendents, et adjektiivatribuudiga fraasides kasutatakse enamasti adessiivi, genitiivatribuudiga fraasides kõige sagedamini inessiivi. Viimasel juhul ei ole tendents küll niisama selge - peaaegu sama palju esineb partitiivi, võimalik on ka adessiivi kasutus, esineb ka kaassõnaline aegu (vt näide 14). Inessiivi ja partitiivi kasutust sarnases kontekstis võib ilmselt toetada ka analoogia.

\subsubsection{Läänemurre}

Läänemurde alal sarnaneb kasutus saarte murdega, inessiivivormide osakaal on siin aga veelgi suurem: morfoloogiliselt märgendatud korpuses on sõna aeg inessiivivormide hulga poolest neljandal kohal (erinevalt saarte murdest on inessiivi rohkem kui genitiivi).

Vormivalikul kehtivad samad tendentsid: adessiivne ajamäärus esineb enamasti koos adjektiivatribuudiga, ligi pooltel juhtudel koos pronoomeniga see (sel aal, sel aeal, sel ajal), (15-17), ülejäänud adessiivsed esinemisjuhud on valdavalt koos adjektiiviga (18-19) ning mõnel määral pronoomeniga (20).

(15) Tor: vaatta sis=te olette juba isegi targad ku sell aal (.) kui neid soldattisi vanal aal püitti (.) ja siss no- noored mehed joosnd ära (.)

(16) Tõs: noo juu pannid ol'id 'ikke ligi koa siis juba sell aeal=ja (.) et liha koa 'praetti=ja (...)

(17) Kul: nisukke puhvaikka oli seal 'sel'gas (...) sell ajal põlnd püksi='plaani (...) oleks sull siis püksid kaa olnd (...) 
(18) Var: vimmad tulid koa päräst ’poole vanal aal oli näid `rohkem aga nüid nüid ei ole (.)

(19) Mih: no ma=i tea 'öetti vist jahh lugemisele jahh viimasel aeal ’öetti ‘ikka ‘kihlusele aga muud `kihlust polnd seal

(20) Tõs: aga villane `ekke (.) nohh villane `tehti juu omal aeal koa=kõik koduse `tööga (...)

Omastavas käändes substantiivi või personaalpronoomeni kõrval on kasutatud inessiivikujulist vormi 'aegas (21-25, kokku 49 näidet). Erinevalt saarte murdest ei leidunud aga samas tähenduses partitiivikujulisi määrusi, partitiivi on kasutatud kestuse väljendamiseks kvantorifraasi koosseisus (natuke aega). Partitiivivormide hulka korpuses suurendavad ka püsiühendid (aega saama jms).

(21) Var: oli siis suur `joomene (.) ja rugi `lõikkuse `aegas kahh (...) siis koa (.) siis oli iä rugi lõegatta sirbiga lõegatti

(22) Mih: aga `musta=ja (.) ja seda (.) kollast (.) seda minu kodu tädi `värvis (...) sõea=`aegas oli `värvisi ei ond=ju `saada (...)

(23) Mär: need ol'id siss (.) tegid siäl vigurid ja siss teest said naerda 'iästi=ja (...) aga mõesa `aeges no siäl ikki siss (.) inimene ol'i jo nii (.) tappettud ja peksettud

(24) Mär: sedä võis iga üks tehä sell=aal kui `keegi `tahtis pühäde `aegas ol'i igä+öhöl ja sõnikku väo=as ol'i igä+öhöl mõn'i tegi täda ‘rukki 'lõikkuse `aegas=ja

(25) Mih: e no ma=i tea ju tal siis ehk `viina koo oli võe (.) minu `aegas enam `kosjas `köimist eij=ond=aga (.) se $=$ oli ennemalt olnd (.)

Vähesel määral leidub nimetavas käändes ajamäärusfraase (9 näidet), sellisena laiendab põhisõna enamasti substantiiv.

(26) Hää: ja me- siiss 'võt' sime 'kätte=ja läksim `luht+ruudist läksime 'väl'la kella kahessamma aeg (...) ja siss 'tant' sisime ja pidustasime siin Kablis ära (...)

(27) aga nüid jahi+mehed lasevad nad maha `rohkem (...) `ol'li juhus (...) sui eena $=$ aeg (...) mull `ol'lid kanad siin+samas `akna all (...) 
Näide 26 on selgelt tõlgendatav ajamäärusena, näide 27 jääb aga ambivalentseks: pauside vahel on see interpreteeritav eraldiseisva fraasina või lausena (mis samas siiski sündmust ajas lokaliseerib) .

Läänemurde alal on vormid jaotunud üsna selgelt: koos genitiivatribuudiga esineb inessiivivorm, adessiiv esineb aga koos ühilduva adjektiivatribuudiga. Seega võib väita, et inessiivivorm toimib siin kaassõnalaadselt, väljendades teatavat ajalist suhet; adessiivses fraasis aga kannab aeg põhitähendust.

\subsubsection{Keskmurre}

Keskmurdes torkab silma nominatiivi suurem osakaal võrreldes saarte murde ja läänemurdega. Oletus, et see tähendab ka nominatiivi rohkemat kasutust ajamääruse käändena, leidis materjali analüüsis tõepoolest ka kinnitust. Toimumisaega näitavas ajamääruses on täiendiks genitiivatribuut (enamasti substantiiv, mõnikord ka personaalpronoomen). Mõnevõrra kasutatakse nominatiivsena ka ühendit see aeg. Pronoomeni see kasutuse puhul on tavalisem adessiiv (näites 34 ongi keelejuht kasutanud samas tähenduses erinevaid vorme).

(28) Äks: siija+`samma (.) tegin küll küini (.) suure küini kuhe ja (.) aga $\mathbf{s o ̃ a}=\mathbf{a e g}$ 'pan'tti põlema ja põles kõege einttega ära (...)

(29) HMd: meil oli ju riigi (.) juht oli ju siis 'keiser (...) aga 'keisre valitsuse aeg oli kibe elada (...) raha `saamene oli väga väga vähä (...)

(30) Pil: mina oma oma laadal käigu aeg ’pus'si laadal ei näind (...) `siukkest 'as'sa ei olnd (.)

(31) SJn: peig+mes tul'li pruudi=kodu (.) 'võt'tis pruudi omale kõrvale (.) $\mathrm{kas}=\mathrm{ta}$ `ol'li siis talve=aeg ehk sui (.) suur jagu 'ikki talve=aeg ol'lid pulmad (...)

(32) Kei: kas ärjad olid paremad siis=või ärjat oid vist tugevamad neil või kudas $s e=o l ' i d=a g a$ nüd minu aeg siiss siis ‘akkasid juba inimesd ’akkasd oostega `künma enam `ärgi ei pidand

(33) Pil: siis ma laadalt vel alatti krõbistasin neid krõbi `kaunu kass sina said neid veel sinu aig ol'i neid veel

(34) HMd: kardulest=ja kaalikkaid ja (...) kas `naireid ka `söödi seda `aega ka mälettad ei 'naireid sie aeg ei 'ültsi ei old seda ma ei tia kass neid sell aeal ei `oldgi vist 
Nominatiivset ühendit saab nii mõnelgi puhul kõnekeelses tekstis interpreteerida mitmeti (vt nt 35 - võimalik pidada ka öeldistäiteks, seda nii keskmurdes kui ka mujal), keskmurdes on aga märkimisväärne selgelt määrusena tõlgendatavate fraaside osakaal.

(35) Amb: aga siis lõi püs'si+rohu suitsu+'aisu tua täis siis oli sellega ädas se oli `talve aeg kuda nüd selle suitsu `väila suab ja pärast olen ikke ütteld et kui oleks mulle

Adessiiv on ajamääruse käändena valdav, siingi on suur osa pronoomeniga see moodustatud ühenditel (36-37), adessiiv on peaaegu ainuvõimalik adjektiivse täiendiga (adjektiivatribuudiga) ühendites (38-39), ent selle kõrval on samavõrra näiteid ka ühendite kohta, kus täiendina toimib substantiiv või personaalpronoomen (40-43).

(36) Juu: aga `un'tta ol'i paelu old `metsas (.) sell=aal ol’i vägä `ränkkä 'un'tta (...) jahh (...)

(37) SJn: mud'ugi vas'ikkad ol'lid sell=aeal kellest `sül'tti 'tehti vas'ikka lihast ja siss (...)

(38) HMd: liha oli koo vahel `ikka nattuk siis oli vähä liha vanal aeal äga siis nii+'bal'lu pöln (...)

(39) SJn: (.) kui mina noor ol'lin (.) nüid viimasel aeal no nüid nää ’akkast juba `rohkem ühel pool (...) `ikke kahel pool ol'lid pulmad (...)

(40) Amb: üks+gord 'ütles `Ambla õppettaea kaa sedasi leeri aal (.) et (.) kui võttatte `tienijad 'endile (.) siis `tehke nii (.) et luud on seina naal ja minge sealt 'müöda nii et se luud pikkali maha kukkub (.)

(41) Pil: vatta kissi `aknid kohe teeb (...) need tulevad juba teha kõik aga siin e töö aeal (...) ja siis=e (.) said kaa `aknad `ette (...)

(42) Amb: kudas (.) 'ikka (.) ahh korruttamise aal (...) korruttamise aal vokk käib teisip+pidi (...) et `nüöridel tuleb nisukke ris’t tuleb kaks `nüöri pial ris't tuleb senna (.)

(43) VJg: parun Toube ol' $i$ Vuorel siis (.) minu=aeal (...) no $=\mathrm{ja}=\mathrm{ja}=\mathrm{ja}$ siis Vuorel eij $=$ ole $(\ldots)$

Lisaks esinevad korpuses mõned üksikud näited (tugevaastmelise) inessiivi kasutamise kohta (viiest juhtumist neli personaalpronoomeniga (44), üks aga hoopis omamoodi konstruktsioon (45), millele võib paralleele leida lõunaeesti murretest). 
(44) Kei: minu `aeges sai vardaga pekset(tud) ja nüid kõige `viimaks veel sai pindaga peksettud (.)

(45) Amb: siis nii+'muodi on sis=se elamine mõne+sugune see ei ole ühe+sugune mitte (...) nagu näette suvel 'aeges mull on omal müt's pias `praega (...) teesed on 'pal'la peadega kõik (.) aga (.) mina kardan 'külma piast (...)

Seega võib öelda, et nominatiivi kasutatakse keskmurdes samamoodi kui saartel ja läänemurdes inessiivi (siin on võimalik seos tugevaastmelise inessiivi esinemisega), adessiivi kasutus on aga laiem. Võrreldes teiste murretega ei ole samas adessiivi kasutus nii selgelt valdav ühendis see + aeg: koguhulgast on nominatiivseid vorme ligi kolmandik, teistes murretes on adessiivsete vormide kõrval vaid üksikuid nominatiivseid esinemisjuhte. Nominatiivi rohke kasutamine ajaväljendites eristabki keskmurret teistest murretest.

\subsubsection{Idamurre}

Idamurde tekstides on toimumisaega väljendatud enamasti adessiiviga (kokku 67 juhtu), sõna aeg adessiivivormi (aal, aeal) täiendiks võib olla niihästi substantiiv, adjektiiv kui ka pronoomen. Ligi kolmandikul juhtudel (23 juhtu) on täiendiks pronoomen see (46-47), ülejäänute hulgas on genitiiv- ja adjektiivatribuuti peaaegu võrdselt (vastavalt 19 ja 18 juhtu).

(46) Avi: nohh (.) ma räägin sedäsi (.) nagu sell=aal ‘üel’di (...) siis seda kangast 'üel'di vattal (...)

(47) Avi: aga siis sell=aeal õl'i siin Vad'il õl'i suur jõgi=ja

(48) Pal: teestega ühes `tööttama ja iga pääv vähäm `saama ku teesed saavad ja `tahtsin siis mässu aal kahh kurat tulla sialt Süvalõppest `siija Luuwale et $=$ sis lähemalt kuulen

(49) Trm: ja kasukkas=ja kuub need=õl'id sel'jas ja tiad 'vüöga kõvast talve=aal külmaga kõik kin'ni `pandud jaa

(50) Avi: aga ikke `enne jüri+'bääva (...) jüri+bääva aeal (.) suur osa ikke sie nagu (--) 'las'ti loomad jüri+bääva ommukku (.) ’kokku (...)

(51) Trm: ja nüüd=ned 'tal'lid=o praaegu=viel ülevel (...) `mõtle=ku vanal aal sis=net (.) 'ütleme Kattariin'i aeal (.) nied=e kased mis siäl rohu=aas (.) rohu=aed siäl õtsas (...) 
(52) Pal: niij=et (.) ull=krahv ol'i (.) vanal=aal kui (.) Vened val'itses suur (.) ull Nikkulai es'imine (...)

(53) Trm: ma=tsi õl’i koa `tarkkusi ja õijendusi miss kõik `õskasivad ära teha vana $=$ 'aeksed in'imesed a 'nüitsel aal nüd ma $=\mathrm{i}$ 'tiagi $=$ et 'noottasid onn ei tia

Adessiivi kõrval on võimalikud ka teised väljendusviisid (nominatiiv, genitiiv + sees). Nominatiivi on kasutatud peamiselt koos substantiiviga (üks näide personaalpronoomeniga, üks see aeg). Vähemasti pooled korpusest leitud nominatiivivormid ei ole aga määruslikud, ka ülejäänute hulgas on rohkesti mitmeti tõlgendatavaid juhtumeid (nominatiivivorme kokku 39, neist määruslikku tõlgendust võimaldab 22 näidet, viimastest omakorda 5 väljendavad kestust). Näited 54-55 on üsna selgelt tõlgendatavad määrusena, ent näidet 56 on võimalik interpreteerida ka teisiti (subjektina, millele järgneb katkestus, määruslikku tõlgendust toetab küll samas lausungis esinev sügise, ka järgnev proadverb siis võib viidata samale fraasile).

(54) Avi: esmas+bääva ommikku siis siis ‘an'tti `süija ja siis tul'ime siija nohh siin siis esmas+pa 'lõuna aeg sõime siin esmas+pa `õhta tõisi+ba ommikku siis läks pulm siit jällä siis ära sedasi siis

(55) Pal: ju siis=kui `kastma akkad ja `enne võib ka `panna aga `kastmese aeg mee oleme pannud kui `ikke `kastma siis (--)

(56) Trm: jaa üks neist õl'i (.) nii kärme et taa sial 'iattand (.) sügise muidugi ja sie mar'di+bäeva aeg õl'i (.) siis=õl'i juu nagu kõik ju 'tõmmas iasse $=\mathrm{ja}$

Idamurde vormikasutus ei ole nii selgelt jagunenud kui teistes põhjaeesti murretes: adessiiv esineb kõikides kontekstides; genitiivatribuudiga on kasutatud ka nominatiivi, ent siiski pisut vähem kui adessiivi; lisaks on paljud näited interpreteeritavad mitmeti; fraas esineb positsioonis, kus määruslik tõlgendus ei ole ainuvõimalik. 


\subsection{Kirderanniku murderühm}

\subsubsection{Rannamurre}

Nii ranna- kui ka kirdemurdes on toimumisaja väljendamiseks kasutatud peamiselt adessiivi. Partitiivi on kasutatud kestuse väljendamiseks, leidus üks näide (57), mida võib tõlgendada toimumisajana, näidet 58 ei saa aga ühemõtteliselt selgelt interpreteerida.

(57) Kuu: ei=juba sie oli kui nämäd ärä tulid sie oli *Pietri aik (.) kui sie *Pieder senn (.) *Kaarel kahe+doist+*kümmene ärä voit (.) ja ott meilt üle (.)noo siis (.) sidä *aiga oli sie suur katk (...)

(58) Kuu: nojahh no sis (...)*muidugi (.) kudas siis *keski (...)*arvasit kass se *pruudi $=$ puolt $(\ldots)$ vai peik + mihe $=$ puolt $(\ldots)$ siis $(--) *$ pulma $=*$ aiga (...) no kui (...) e *nenda enämb (.) vaea *ruttemi oli teha sedä siiss *muidugi (...)

Mõnevõrra (6 juhtu) võib leida ka määruslikku nominatiivivormi, suurem osa näiteid on siiski ambivalentsed (nt 60 - võimalik pidada ka predikatiiviks), ehkki leidub ka selgelt määruslikku kasutust (59).

(59) Jõe: vanast *püitti jahh rüsadega minu=aeg on *täijeste olnd (...) lõhe+büid ja *räime rüsadega kaa (...)

(60) Kuu: sie oli *sinne vahe+*baikku eh (...) ei=juba sie oli kui nämäd ärä tulid sie oli *Pietri aik (.) kui sie *Pieder senn (.) * Kaarel kahe+doist $+*$ kümmene ärä voit (.) ja ott meilt üle (.)

Leidus üks näide kaassõnakonstruktsiooni kohta (genitiiv + sees) (61).

(61) Jõe: noo tuli *vasta ja sis siel *ostas ja *kauples ära ja siis *viedi e-e *viedi e si- meil siin meil *ikka oli (...) minu aja=sies *ikka olitte hobused

Adessiivivorm on rannamurdes kasutusel aga kõigis kontekstides, niihästi adjektiiv- kui ka genitiivatribuudiga. Siingi leidub hulganisti ühendit sel ajal (aal, aeal) (16 juhtu), adessiivne vorm aal (aeal) esineb niihästi koos adjektiiviga kui ka substantiivi ja pronoomeni genitiivivormiga.

(62) Hlj: nii et=et mina neid nägin aga *sellal enamb ei *tehtud aga minu isa *ütles (.) sie maja (.) lahuttatti nüüd sell=aal ära kuss täma minu isa elas $(\ldots)$ 
(63) Kuu: ja tulid tagasi *jälle sell=aeal kui (.) *arvasid sell- (.) *selle alukse *tühjaks said *jälle tulit (...)

(64) Jõe: eks neid *enne vanal ajal vähe old egas *muidu *suures *käinud kui (...) kalal (.)

(65) Jõe: neli *lippu on sial sies (...) suvisel aeal ja alatti sial Pal'diski (.) Lohu + salu nieme $=*$ otsa kohas

(66) $\mathrm{Hlj:} \mathrm{sis=e} \mathrm{*karttulid} \mathrm{käisin} \mathrm{*noppimas} \mathrm{ja} \mathrm{(.)} \mathrm{mõisas} \mathrm{(.)} \mathrm{kui} \mathrm{(.)} \mathrm{mõisnikku}$ aal (.)

(67) Jõe: aga aga *jaani+*bääva $=$ aeal tuond $*$ silgud=ee *sinne (.) $*$ suure + ma $=$ ära $*$ tulge $*$ korjama $(. .$.

(68) Hlj: ja siis vedasimme jääd (.) *talvel jää ajal (.) jääd müöda *jälle *paadi *kaugemalle ja siiss (.) tuli ise kaa *väl'ja

Niisiis on ajamääruse käändena valdavalt kasutusel adessiiv, väga vähesel määral leidub nominatiivset kasutust.

\subsubsection{Kirdemurre}

Kirdemurdes on kasutus rannamurdega sarnane, ajamäärusena on valdav adessiiv, mida kasutatakse nii genitiivatribuudiga (substantiiv, personaalpronoomen) kui ka adjektiivatribuudiga. Leidub ka nominatiivset ajamäärust, ent selgeid juhtumeid on siiski vähe (nii nagu ka rannamurdes), enamasti on tõlgendada võimalik mitmeti (määruslikku tõlgendust võimaldavaid nominatiivseid fraase leidus kokku 6). Näiteks on näites 69 võimalik pidada nominatiivset fraasi määruseks, ent samas võib see olla ka suulisele keelele omane joon (katkestus, parandus).

(69) Jõh: *peidetti *vällä siss (.) *õtsitti (.) tegi peräst taga ja *tehti kõik+sugu vigurid ige ku *nuori õli *palju kuos (.) vanad mehed õlid siis ei *tehned nii *paljo (.) *nuori õli siis *ikke *müllätti *müllämise aeg * Iõuna=ajal sis (.) *võetti *luobitti vett ja=ja (.) *müllätti *sinne (.) jube õli (...)

Nagu öeldud, esineb adessiiv niihästi ühilduva kui ka omastavalise täiendiga. Nagu teisteski murretes, on suur hulk esinemisjuhte koos pronoomeniga see (16 esinemisjuhtu). Arvuliselt kõige enam esinemisi on substantiiviga (42 juhtu), adjektiividest laiendid on tüüpilised aega iseloomustavad sõnad (vana, nü̈̈dne jms; kokku 14 juhtu). 
(70) Jõh: *peiju=*poisid *valvama järälä=et *pruutti varastatta ei saa (...) ja sie aga nüüt mee siis minu *pulma $=\mathbf{a e a l}$ seda küll=eij=õld et *pruutti varastetti aga *ennemast õli õld küll (...)

(71) Jõh: kolm *päivä (.) tegid *eina=aal (.) kolm e-es=see *vakka+maa *rukkid ja (.) *vakka+ma *õtri pidid *niittama (...)

(72) Vai: kääd seda+modi *ninda (.) siin (.) pihu pesa sai *kukkuda siis `täitsa *luomuliguld (.) *päävä aeal siis (.) `lendas *juure (...)

(73) Vai: ma mälettan õlin (.) Meri+güläs säl (.) esimise *ilma+sõea aeal raijutti (.) *metsa *paljo maha $=$ ja siis õli *kannustik viel (...)

(74) Jõh: nii=et seda *tehnikka oli *ikka vanal aeal kaa aga (.) aga sie $<$ com $>$ naerdes $</$ com $>$ oli kõik ni vie (.) oma ${ }^{*}$ muodi *tehnikka *jälle $=$ et inimestele tegi $*$ irmu $=$ ja $($.

(75) Lüg: nied ei õld nüd *niisikkesed kui *nüütsel aeal onn aga *ikke (.) *nüöppidega *saappad õlivad=ja (.)

Kirderanniku murderühm on käändekasutuselt seega üsna ühtlane, kahe murde vahel olulisi erinevusi esile ei tule. Niihästi kirde- kui ka rannamurdes kasutatakse toimumisaja väljendamiseks valdavalt adjektiivi, nominatiivi on mõnevõrra kasutatud genitiivatribuudiga.

\subsection{Lõunaeesti murded}

\subsubsection{Mulgi murre}

Mulgi murre eristub teistest lõunaeesti murretest selle poolest, et sõna aeg käändevormide hulgas on siin nagu põhjaeesti murreteski kõige kasutatum käändevorm adessiiv (71 juhtu). Adessiiv on kasutusel eri kontekstides, esinedes niihästi ühilduva (76-78) kui ka omastavalise täiendiga (79).

(76) Hls: sii vana Kaubi Pokk mõis't tal sel kõrva raha `vällä sõss (.) miss selle iist (.) sell=aal omm sii preemija ollu viis' rubla undi kõrva pält (...)

(77) Pst: nohh mul'k kasvat's lina (...) 'tartlene ei old sell aeal lina kasvatten $(\ldots)$

(78) Krk: kalu `püintti (.) vanal aal `mõrdege (...) ja nii mõrra (.) valmistide vitsest=jaa (.)

(79) Trv: enne miu olli (.) miu=aal olli joba massina pessu+massina (...) aga enne miu viil=ma mäletta ka me siin viil `pes'seme m- taren (.) 
21 korral esineb fraasis pronoomen see, 17 korral on laiendiks adjektiiv, 23 juhul substantiiv, 4 juhul personaalpronoomen, 6 juhul ühilduv pronoomen (oma).

Adessiivi kõrval on vähemal määral kasutatud teisigi vorme, leidub nominatiivset kasutust (14 juhtu), mis on aga taas sageli mitmeti tõlgendatavad (näites 80 on kindlalt tegu määrusega, näites 81 toetab määrusena tõlgendamist samas lausungis esinev adessiivne määrus). Enamasti on nominatiivses ajamääruses laiendiks substantiiv (11 esinemisjuhtu), ühe näitega on esindatud pronoomen see ja personalpronoomen (mee aig).

(80) Krk: üits+kõrd emä päävä+dõusu aig üttel'=et (.) tu=ma pane rohi 'pääle $=\mathrm{ja}(\ldots)$

(81) Krk: ja=sõss (.) ja temä olli ka (.) seande (.) kauba ajaje (...) omal aal=ku (.) Rimmi sõa aig=ja (.) ja enne Rimmi sõda (.) sõss olli temä (.) alatti 'Riiga viinu mett (.)

Mulgi murdes leidub ka näide kaassõnalise konstruktsiooni kohta (genitiiv + sees $)(82)$.

(82) Trv: aga (...) tõine nõnda selle aa seen ei saa viil (...)

Mulgi murdes (nagu ka Tartu murdes) eristub kaassõna 'aegu vormiliselt partitiivist (‘aiga), toimumisaja väljendamiseks kasutatakse esimest (83), partitiivi kasutus ajamäärustes piirdub kestuse märkimisega.

(83) Krk: kõik `kat’teve ja puha 'kat’teve ärä (.) pääle sõa eij=ole ‘ütte ämp saija (.) ee $=\mathrm{ka}($.$) `enne (.) `ennemi sõa `aigu ol’li egät (.) nättä (...)$

Toimumisaega märgitakse seega üldiselt adessiiviga, genitiivatribuudi puhul võib esineda ka nominatiiv.

\subsubsection{Tartu murre}

Tartu murdes on kõige selgemalt võimalik eristada partitiivi ja postpositsiooni. Partitiiv esineb üldiselt kujul ‘aiga, sellisena esineb sõna tüüpilistes kestust märkivatest väljendites. $u$-line ‘aigu esineb postpositsioonina substantiivi või personaalpronoomeni järel (kokku 43 esinemisjuhtu), märkides toimumisaega.

(84) Võn: noohh (.) ega siss miu=aigu ss=olõ söögi+' buuduss 
(85) Ote: no aga toda kodu=tulõkkit toda 'uutsõt 'õkva nii+gu aina=`aigu oodõttass `päivä pilve alt (...)

(86) Nõo: liinan oss=abi saanu kohe (...) siss ku=ta kodu tulli (.) lõun=’aigu vai mes=ta kodu 'tul'li (.)

(87) Rõn: kas=na=ssiin siss (.) targemba=l'li (.) Rõngu='mõisan ollu (.) e vana (.) e kr- kr- krahvi `aigu (.) ollu sääl ollu=jo (.) eq e seo (.) 'tappa+daill (...)

Murdekorpuses esinevad adessiivsetes näidetes (23 juhtu) esineb enamasti sõnaühend toll=aal (ka toll=ajal - kokku 16 juhtu, lisaks üks kord sell=ajal), mõned näited ( 5 juhtu) on adjektiivatribuudiga sõnaühendite kohta ning üks näide (90) substantiivse täiendi kohta.

(88) Ote: maa kedrässi=ja kudasi kyik'=ja (...) no lastele kyik' ega *poodist toll $=$ aal ess $=$ ole saada nigu nüid omm $(\ldots)$

(89) Nõo: eittäp siss=esi sääl (.) kõrdsi pingi=päle magama (.) kõrdsin `ol'l’i jo vanal aal (.) suur pik'k laud `olli üle kõrdsi+dare sääl katsi+bäedi ol'iva pengi pikkä pengi (.)

(90) Rõn: suure $=$ inemise seivä 'lavva $=$ man (...) mihe seivä $` i s t u=j a$ naese 'ol'liva (.) vai tüt- suure tüdrukku='ppis'ti jala=päl (...) niij=ol'li vanast tuu=elu meil minu (ka-) (.) kasu=põlve aal (.) sedä+visi maa=siss (.) sai inemis meid (.)

Mõnevõrra esineb nimetavas käändes määrust (toimumisaja tähenduses 5 korda), ent taas tuleb osutada tõlgendamisraskustele (vrd näiteid 91 ja 92 - kui esimeses on selgelt tegu määrusega, siis teine eraldiseisva fraasina jääb ebamääraseks).

(91) Rõn: sai jõulune aig ’juvva toda (...) ja jäij=üle `uvvess *aastass kahh $\operatorname{viil}(\ldots)$

(92) Nõo: vanast ollip=puu `ratta ilma ravvatta `kos'kil `rauda ess=ole kõik ol'i puha puu (...) noq (...) kesk+üü aig (.) iluss kuu+'valge üü küll nagu sügisene üü no `umbess `septembri kuul (...)

Tartu murdes näib olevat vormiline jaotus üsna selge: partitiivi kasutatakse kestuse väljendamiseks, toimumisaega väljendab kas genitiiviga kaassõna ‘aigu või adjektiivatribuudiga adessiiv. 


\subsubsection{Võru ja Setu murre}

Murdekorpuses on Setu murre loetud omaette murdeks, ent järgnevalt on Võru ja Setu murdes esinevaid väljendeid käsitletud koos, Setu murdes oli käändevormideks märgendatud sõnede hulk väike, vormikaupa vaadeldes olid tulemused põhiosas sarnased.

Võru ja Setu murdes on kõige suurem partitiivsete vormide hulk, vormist lähtudes ei saa eristada sõna aig partitiivi ja võimalikku kaassõna, vormilise kokkulangemise tõttu on aigu ja aigo allpool loetud partitiivsete vormide hulka (süntaktiliselt on küll põhjendatud nende vormide liigitamine kaassõnaks, nagu edaspidisest nähtub).

Võru murde silmatorkav erijoon on vormi ‘aigu, ‘aigo (mõnikord ka ‘aiga) kasutamine koos pronoomeni too alalütleva käände vormiga. Sellisel kujul võib seda pidada selgelt iseseisvunud (pro)adverbiks; analüüsitud näidete hulgas oli vaid üks, kus pronoomen on partitiivis (94).

(93) SeI: ja õdagu jäll õ 'ilda (...) an'd' kat's'+kümmend `tengä (...) jahh (.) ja tuul+`aiga sai (...) õ kat's'+kümmend 'tengä (...) sai pää+rät't' (...)

(94) Rõu: es=sak=kunagi kõttu+däüt (.) inemiis'il ol' näl'g (...) tuud aigu noq ‘ütle=et (.) et mull esä üttel' nohh tää=ol'l'=õks lat's' 'or'juse `aigu (.)

Selline ühend ei ole tundmatu sugulaskeelteski: näiteks esinevad soome keeles väljendid sillä aikaa (enamasti samaaegsuse tähenduses 'sel ajal kui') ja tällä aikaa. Samalaadsed on ka ühildumatud konstruktsioonid, nagu pitkästä aikaa, siksi aikaa. Elatiiv ja partitiiv võivad ajaväljendites kanda mõnikord samu funktsioone (eesti keeles nt ammust ajast ammust aega, vt Rannut 1960). Ühildumatute konstruktsioonide esinemise ühe seletusena võib neid käsitada osana kvantorifraasist (*tollel ajal/hetkel aega, *ammu(se)st ajast/hetkest aega), kust peasõnaks olev kvantor ise on kadunud 6 .

Omamoodi huvitav küsimus on, miks esineb ajaväljendites rohkesti nimelt pronoomen too, mitte aga $s$ 'eo. Vaid ühel korral esines korpuses s'eo aigu (95), üks kord ka sell='aigo (96), viimane võib aga olla ka küsitlejast mõjutatud (kindlasti on seda samas lausungis esinev sell=aigo). Kirjakeele põhjal on Renate Pajusalu (2006) leidnud, et sel ajal võib viidata nii minevikule kui ka tulevikule, samas kui tol ajal saab viidata ainult minevikule. Võru murdes on demonstratiivpronoomenite vahekorrad

6 Tänan selle osutuse eest professor Helle Metslangi. 
teistsugused, ühe võimaliku seletusena võiks siiski oletada korpusetekstide eripära - räägitakse enamasti kaugemast minevikust, mille puhul too võiks samamoodi nagu ruumi puhul viidata kaugemale ja s'eo lähemale.

(95) Har: aga nohh nigu nüüd=omm yks s'eo `aigu 'tet't'i yks joba 'kykkõ 'praat't' $\mathrm{i}=\mathrm{ja}($.$) sül'd' \mathrm{i}=\mathrm{ja}$ praad' $\mathrm{i}=\mathrm{ja}(. .$.

(96) Plv: (Küsitleja: no miss nü̈̈t kor'attass (.) nüüt sell aal (.) aol (.)) nohh sell=aol eij $=$ ole muu 'kor'jamiist no palohka 'kor'jamine umm (.) sell=`aigo=jaq õõ naa ‘ütlese ka viil `valge olevat nohh (.)

Võru ja eriti Setu murdest võib aga leida ka selliseid näiteid, kus adessiivis adjektiiv vana on kombineeritud partitiivse aeg-sõnaga (97). Ent esineb ka ebatüüpilist kombineerumist adessiivse substantiiviga (99), mida saaks tõlgendada kaassõnalaadse kasutusena. Erandlikult esines inessiivikujulise ‘aeges kõrval adessiiv ka keskmurdes (Amb): nagu näette suvel ‘ages mull on omal müt's pias 'praega (...) teesed on 'pal'la peadega kõik).

(97) SeP: suur' kaus'i+täis muna+'putru (...) ja küdset't'i vat's'k' (...) vanal=aiga $(. .$.$) ess mindä nii =\mathrm{ku}$ nooq $(. .$.

(98) Har: mhmh (...) pal'l'u=tuu 'kes+kuul' mittu 'aastat siss tuul `aigu ol'l' (...) tuul `aigu ol'l' säidse 'klas's'i (...)

(99) SeL: õõ jälq 'tul'l'i `talgost kodo siss sääl kul'attad'i 'lüüd'i 'pil'l'i=ja (...) ja `juud' $\mathrm{i}=\mathrm{ja}$ `süüd' $\mathrm{i}=\mathrm{ja}$ (...) poolõ üül=`aiga sai (--) kodo (...)

Adessiivi on kasutatud suhteliselt vähe (kokku 27 korda), enamasti koos ühilduva (adjektiivse) täiendiga (100). Leidus ka paar näidet, kus adessiivne sõnakuju on kombineeritud genitiivatribuudiga, ent mõnel juhul võis oletada küsitleja (kasutanud küsimuses adessiivi) või kirjakeele mõju üldisemalt (kasutatud vormi ajal).

(100) Har: pulman ol'l'=yks säänt=sammanõ (.) iks sama (...) yks peris vanal aol ol'l' aga nohh nii siin uuwõmbal aol (---) 'pille ka=ja (...) yks ol'l' muid=ja (...)

Niisiis on Võru ja Setu murde alal ajamääruse funktsioonis üldistunud partitiivikujuline vorm, mida ei ole võimalik eristada samakujulisest kaassõnast. Adessiivi kasutus piirdub suuresti fraasidega, kus substantiivi aeg laiendab adjektiivne atribuut. 


\section{Sõna aeg vormide kõrvutav analüüs}

Murdekorpuse tekste analüüsides leidis kinnitust oletus, et sõna aeg kasutuses võib murdeti täheldada erinevusi, mis puudutavad niihästi käändevormide sagedust kui ka kasutust erinevas keelelises ümbruses. Piirkonniti ilmneb erinevus esiteks suurema varieeruvusena Põhja-Eesti läänepoolsel alal, teiseks kaldutakse eri murretes kasutama isesuguseid keelevahendeid.

Adessiivne vorm on laiema kasutusega, mõnes murdes (kirderannikumurded, idamurre, Mulgi murre) on see ajamääruse käändena valdav igasuguses ümbruses ning kombineerub nii genitiiv- kui ka adjektiivatribuudiga; mõnes (saarte murre, läänemurre, Tartu, Võru murre) ühendub aga peamiselt adjektiivatribuudiga (ehkki ka neis murretes esineb üksikuid genitiivatribuute). Sellisena ei ole sõna oma nimisõnalisust kaotanud; tähendust kannab sõna $a e g$; lisatud adjektiivide valik ei ole väga suur, need iseloomustavad aega teatud omaduse kaudu (vana, nü̈̈ne, praegune) või määratlevad, paigutavad teatavasse järgnevusse (esimene, järgmine). Nagu jooniselt 1 näha, on murdeti kasutus üsna sarnane, pea kõikides murretes on adjektiivatribuudiga konstruktsioonis kasutatud üldiselt adessiivi (joonise aluseks olevad arvandmed on esitatud tabelis 3 ).

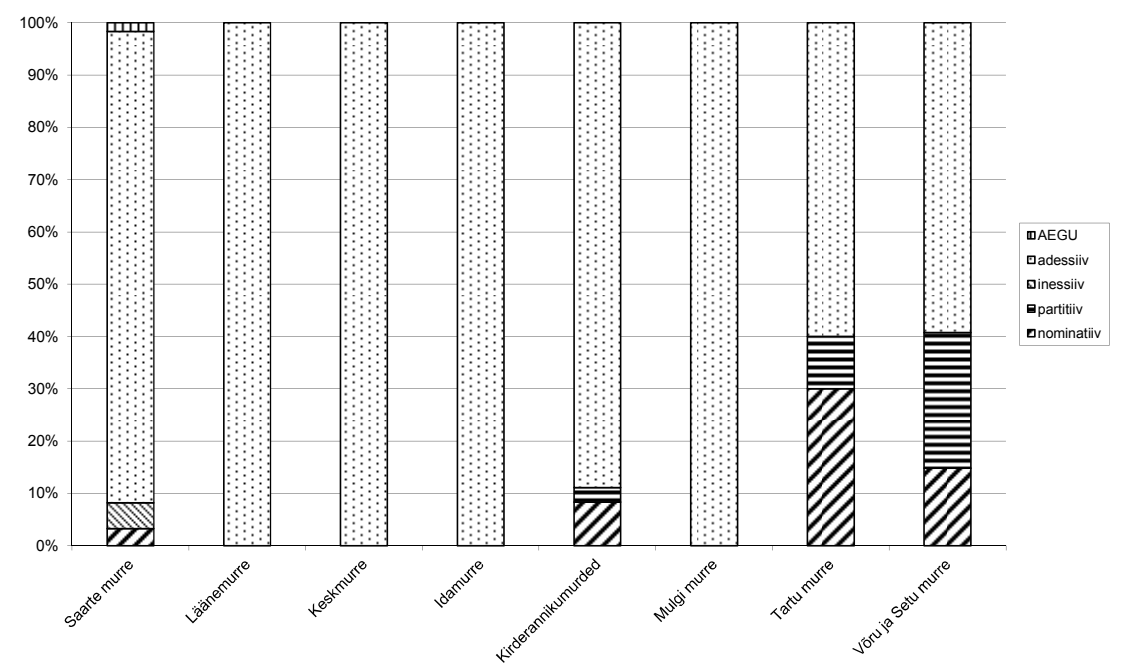

Joonis 1. Adjektiivatribuudiga esinevad sõnavormid ${ }^{7}$

7 Võru ja Setu murde partitiivsed vormid on tegelikult ühildumatud fraasid vanal aiga (kõik Setu näited). 
Kaassõnalaadselt toimivad pigem partitiivi- ja inessiivikujulised vormid, keskmurdes ka nominatiiv: need kombineeruvad genitiivatribuudiga (mitte aga adjektiivatribuudiga). Vormiliselt eristub käändeparadigmast kõige selgemalt `aegu ‘aigu, välja arvatud Võru murde alal, kus võimalik kaassõna langeb vormiliselt kokku partitiiviga. Kaassõnalaadne inessiivivorm on levinud vaid tugevaastmelise inessiivi alal, ehkki nt murdesõnaraamatus on inessiivseid näiteid ka Setu murdest: vanah aoh tuud jo kõnoldi (EMS: 97), ’päivätseh ajoh (EMS: 99).

Kaassõnalaadsust rõhutab laiendite puudumise kõrval ka võimalik tähenduse laienemine (ehkki aeg on iseenesest üldise tähendusega sõna). Sellele näikse viitavat kasutusjuhud, kus sõna kasutatakse topelt (101), samuti on võimalik ajatähendus (samaaegsus) lisada peagu ükskõik millisele sõnale. Tüüpiliselt esineb aeg koos aega märkivate sõnadega ( $p \ddot{a} e v$, lõuna jms), perioodi määratakse tegevuste ja sündmuste kaudu, viimasel puhul võib peale tegevushetke või -perioodi tähenduseks olla samaaegsus, sedakaudu võib aga tähendus veelgi ebamäärastuda: näites 102 ei ole ajakomponent enam tähenduses oluline. Kuna sõna aeg (kaassõnastunud) käändevorm võimaldab lühidalt viidata samaaegsusele, on seda võimalik lisada isegi konkreetset (materiaalset) objekti tähistavatele sõnadele: näites 103 annab fraas aida aeg edasi tähendust 'siis, kui (siin) ait oli'.

(101) Plv: ‘kangõ `kangõ pal'gi iks no `nüütse ao aig iks `säntsit `palkkõ eij=olõq $($.

(102) Mih: $\mathrm{ja}=$ siiss $=\mathrm{e}($. $)$ pere+naene=või pere + mes kis $=$ seal $=$ oli isa=või ema (.) õõ liha jagamise `aegas oli $=\mathrm{s}$ (.) `võttis iga=ühül `pisse (.) jau=sealt (.) ja pani iga $=$ ühül lauwa=piale `ette

(103) HMd: siiss kui magasi (.) magasi aitt veel oli siiss (.) siis oli (...) sie (.) sie oli isa minul pöle neid on (...) ma pöle (.) mina pöle aida aeg (...) perele se leiva muretseja oln (.)

Selline kasutus ei ole otseselt seotud sõna vormiga, samamoodi võib konkreetset eset tähistava sõnaga kasutada ka adessiivi (104), ent seda peamiselt murretes, kus adessiiv on üldine ajamääruse kääne.

(104) Trv: suhkurt ka viil pannime=ja (...) sõss olli ää juvva (...) massina aal või tüü aal (...) jäi nõnda=t (.)

Joonis 2 (andmed tabelis 4) osutab, et genitiivatribuudiga konstruktsioonides on vormilist varieerumist rohkem ja murdeti eelistatakse eri vorme: 
nii on näiteks läänemurdes kasutatud kõige enam inessiivi, keskmurdes nominatiivi, Tartu murdes muust paradigmast selgelt eristuvat kaassõnalist vormi.

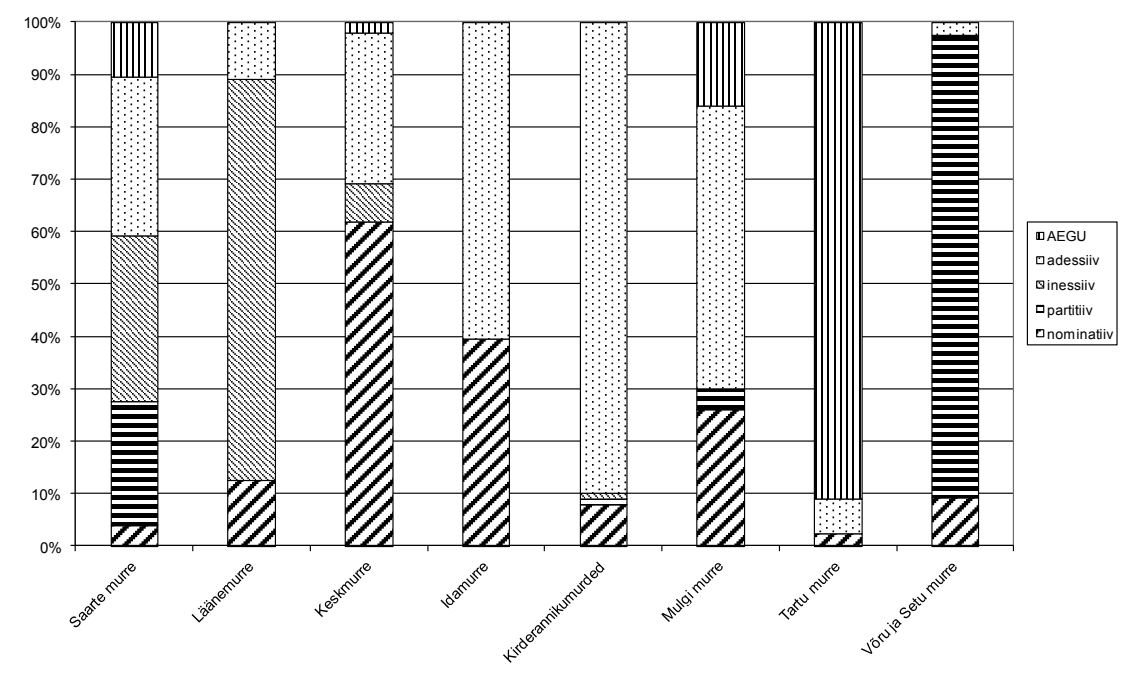

Joonis 2. Genitiivatribuudiga esinevad sõnavormid ${ }^{8}$

Kinnistunud sõnaühend on Põhja-Eesti alal sel ajal (sell=aal, sell=aeal). Omaette sõnaks märgitud keelendit sellal esineb korpuses vähe, on aga võimalik, et kokkuhääldatud sõnaühendis sel aal on vokaal lühenenud, ent lihtsustatud transkriptsioonis kirja pandud tekstides välteerinevus selles positsioonis ei kajastu. Ka Mulgi murdes on kasutatud pronoomenit see ühendis sell=aal, Tartu murdes aga samas positsioonis ühendit toll=aal. Võru murdes esineb samasugusena sõnaühend, kus on kombineerunud adessiivne pronoomen ja partitiivne aeg (tuul=aigu $\sim$ tuul=aiga $)$. Seda saab käsitleda omaette üksusena, ent proadverbina tõlgendamise korral siiski pigem grammatilise üksusena. Täheldada võib aga ka mõne muu sõnaühendi kinnistumist: üsna sageli esineb Tartu ja Võru murdes sõnaühend lõu=aigu, kus esikomponent on lühenenud (EMS: 99 annab liitsõna näite ka Kõpust: lõunaeg (lõunaeg keedeti kartulid viiga)).

Joonis 3 esitab laiendiga see või too esinevad sõnavormid (andmed tabelis 5). Muidu üsna ühesuguse kasutuse puhul tõuseb esile keskmurre,

8 Võru ja Setu murde puhul on aigu ja aigo loetud partitiivivormide hulka, seega on tegelikult kasutus Võru ja Tartu murdes üsna sarnane. 
kus adessiivsete vormide kõrval on kasutatud üsna palju ka nominatiivi, samuti eristuvad teistest murretest Võru ja Setu murre.

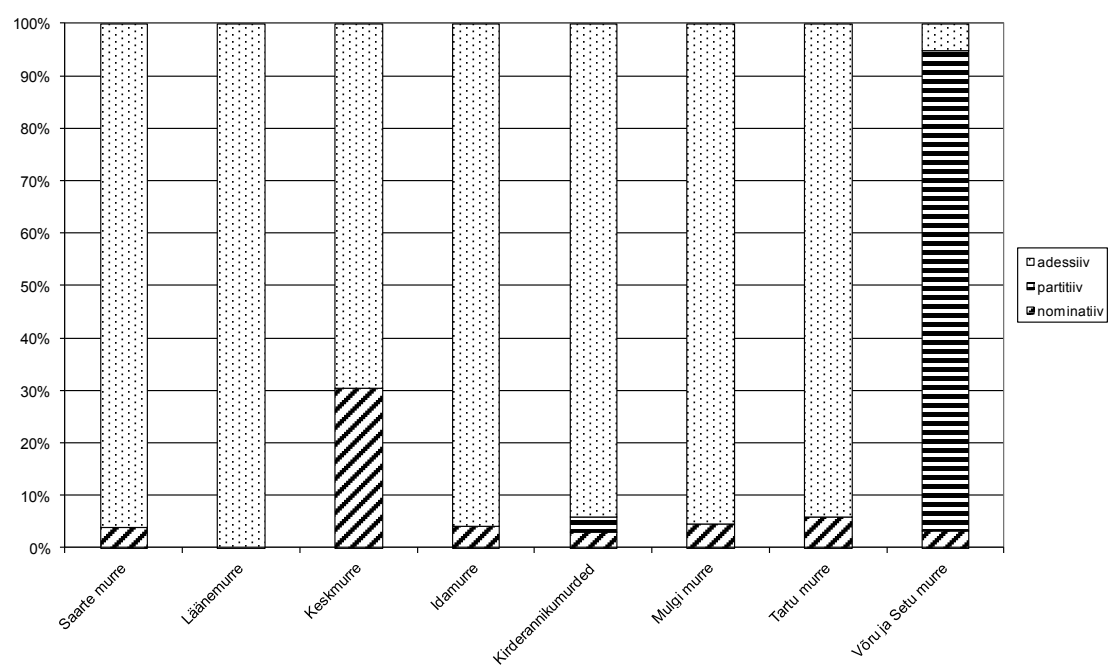

Joonis 3. Laiendiga see/too esinevad sõnavormid

Siinses artiklis on keskendutud morfosüntaksile, omaette käsitlust vääriks aga ka semantika. Praegugi võib analüüsitud materjali põhjal väita, et eri vormide kasutamisel mängib kaasa ka tähendus: mitmes murdes valitakse adjektiivatribuudi ja genitiivatribuudi puhul erinev vorm ning see on ilmsesti seotud tähendusega. Kui ühilduva adjektiivatribuudiga konstruktsioonis kannab põhitähendust sõna $a e g$, siis genitiivatribuudiga konstruktsioonis pigem omastavaline täiend, millele käändevormis aeg annab ajalise lisatähenduse. Seega on põhjendatud ka erineva vormi kasutamine (seda siiski mitte kõigis murretes). Murdeti võib täheldada vormivalikul erinevusi: kui adjektiivatribuudiga konstruktsioonides on kõikjal valdav adessiiv (kõige levinum ajamääruse kääne üldse), siis omastavas käändes täiendi puhul võib näha piirkondlikke erinevusi. Nii on läänepoolsetes murretes levinud inessiiv, mis neis piirkondades esineb tugevaastmelisena, võimalik, et seda toetab analoogia partitiiviga, mida saarte murdes inessiivi kõrval samuti on kasutatud. Võib arvata, et tugevaastmeliste vormide levik on toetanud ka keskmurde nominatiivikasutust (keskmurdes esinevad üksikud inessiivivormid on samuti tugevaastmelised). Ka Lõuna-Eestis on kasutusel mitmesugused konstruktsioonid, seejuures võib Tartu murdes 
teha kõige selgemalt vahet kaassõnalise konstruktsiooni ja käändevormi vahel. Idamurdes ja kirderannikumurretes, aga ka Mulgi murdes üldtendentsina kaht konstruktsiooni nii selgelt ei eristata, ehkki nominatiivi kasutamist genitiivatribuudiga konstruktsioonides võib siiski täheldada.

Sõna aeg vormide varieerumises ja kasutuses võib seega näha mitmesuguseid mõjureid, kahtlemata mõjutavad kasutust näiteks analoogiamehhanismid. Edaspidises uurimises aitaks pilti kindlasti avardada võrdlus teiste ajaväljenditega, ent sellegi väikese ja tavalise sõna kasutus toob välja mustrid, mis ilmselt on seotud nii keelesiseste kui ka -väliste teguritega.

Tabel 3. Toimumisaega väljendavad adjektiivatribuudiga määrused

\begin{tabular}{|l|c|c|c|c|c|c|}
\hline & Nominatiiv & Partitiiv & Inessiiv & Adessiiv & Aegu & Kokku \\
\hline Saarte murre & 2 & & 3 & 55 & 1 & 61 \\
\hline Läänemurre & & & & 45 & & 45 \\
\hline Keskmurre & & & & 25 & & 25 \\
\hline Idamurre & & & & 18 & & 18 \\
\hline $\begin{array}{l}\text { Kirderanniku- } \\
\text { murded }\end{array}$ & 3 & 1 & & 32 & & 36 \\
\hline Mulgi murre & & & & 23 & & 23 \\
\hline Tartu murre & 3 & 1 & & 6 & & 10 \\
\hline $\begin{array}{l}\text { Võru ja Setu } \\
\text { murre }\end{array}$ & 4 & 7 & & 16 & & 27 \\
\hline Kokku & 12 & 9 & 3 & 220 & 1 & 245 \\
\hline
\end{tabular}

Tabel 4. Toimumisaega väljendavad genitiivatribuudiga määrused

\begin{tabular}{|l|c|c|c|c|c|c|}
\hline & Nominatiiv & Partitiiv & Inessiiv & Adessiiv & Aegu & Kokku \\
\hline Saarte murre & 3 & 18 & 24 & 23 & 8 & 76 \\
\hline Läänemurre & 8 & & 49 & 7 & & 64 \\
\hline Keskmurre & 60 & & 7 & 28 & 2 & 97 \\
\hline Idamurre & 17 & & & 26 & & 43 \\
\hline $\begin{array}{l}\text { Kirderanniku- } \\
\text { murded }\end{array}$ & 7 & 1 & 1 & 80 & & 89 \\
\hline Mulgi murre & 13 & 2 & & 27 & 8 & 50 \\
\hline Tartu murre & 1 & & & 3 & 41 & 45 \\
\hline $\begin{array}{l}\text { Võru ja Setu } \\
\text { murre }\end{array}$ & 15 & 144 & & 4 & & 163 \\
\hline Kokku & 124 & 165 & 81 & 198 & 59 & 627 \\
\hline
\end{tabular}


Tabel 5. Toimumisaega väljendavad määrused laiendiga see/too

\begin{tabular}{|l|c|c|c|c|}
\hline & Nominatiiv & Partitiiv & Adessiiv & Kokku \\
\hline Saarte murre & 2 & & 51 & 53 \\
\hline Läänemurre & & & 49 & 49 \\
\hline Keskmurre & 14 & & 32 & 46 \\
\hline Idamurre & 1 & & 23 & 24 \\
\hline Kirderannikumurded & 1 & 1 & 32 & 34 \\
\hline Mulgi murre & 1 & & 21 & 22 \\
\hline Tartu murre & 1 & & 16 & 17 \\
\hline Võru ja Setu murre & 3 & 87 & 5 & 95 \\
\hline Kokku & 23 & 88 & 229 & 340 \\
\hline
\end{tabular}

\section{Kokkuvõte}

Sõna aeg kasutuses ilmneb ühelt poolt märgatavaid piirkondlikke erinevusi, teisalt mõjutab vormivalikut laiend (milleta aeg märrusfraasis esineda ei saagi). Genitiivatribuudiga fraasides on varieerumine piirkonniti eriti märgatav: perifeerias (eriti saarte murdes) näib pilt kirevam, kesksetel aladel ühtsem. Vormieelistused tulevad mitmes murdes selgelt esile, näiteks on läänemurdes genitiivatribuudiga fraasides valdav kääne inessiiv, keskmurdes nominatiiv. Seesuguses kontekstis on mõnelgi juhul õigustatud aeg-vormi tõlgendamine kaassõnana, nagu seda on tehtud eesti murrete sõnaraamatus; kaassõnaks määramist toetab ka asjaolu, et enamasti kasutatakse adjektiivatribuudiga fraasides muud käänet (valdavalt adessiivi). Tartu murdes on kaassõnaline kasutus selgelt eristatav, Võru murdes seevastu on potentsiaalne kaassõna partitiivist eristamatu. Kirderannikumurretes, aga ka idamurdes kaht konstruktsiooni nii selgelt ei eristata, adessiiv on seal ajamääruse käändena valdav. Huvitaval kombel korreleerub mõnel juhul vormieelistustega ka adverbistunud (adverbistuv) sõnaühend see + aeg: kui enamasti on see adessiivne, siis keskmurdes on märgatav hulk nominatiivseid vorme, Võru ja Setu murdes esineb see aga ühildumatu fraasina, kus too on adessiivis, aeg aga partitiivikujuline. Niisiis tulevad sõna aeg kasutuses ilmsiks mitmedki huvitavad tendentsid, siinse analüüsi edasiarendamiseks võiks edaspidi käsitleda niihästi areaalseid mõjusid kui ka semantikat. 


\section{Lühendid $^{9}$}

Avi = Avinurme; $\mathrm{SeI}=$ Ida-Setumaa; $\mathrm{SeL}=$ Lääne-Setumaa; $\mathrm{SeP}=$ Põhja-Setumaa

\section{Kirjandus}

Brinton, Laurel J., Elizabeth Closs Traugott 2005. Lexicalization and Language Change. Cambridge: Cambridge University Press. http://dx.doi. org/10.2277/0521540631.

Bybee, Joan 2007. Frequency of Use and the Organization of Language. Oxford University Press. http://dx.doi.org/10.1093/acprof:oso/9780 195301571.001 .0001$.

Bybee, Joan 2010. Language, Usage and Cognition. Cambridge: Cambridge University Press. http://dx.doi.org/10.1017/CBO9780511750526.

EKG = Mati Erelt, Reet Kasik, Helle Metslang, Henno Rajandi, Kristiina Ross, Henn Saari, Kaja Tael, Silvi Vare 1993. Eesti keele grammatika II. Süntaks. Lisa: Kiri. Peatoim. Mati Erelt, toim. Tiiu Erelt, Henn Saari, Ülle Viks. Tallinn: Eesti Teaduste Akadeemia Keele ja Kirjanduse Instituut.

EMS = Eesti murrete sõnaraamat. I, $1(a-a j u) .1994$. Koost. Anu Haak, Evi Juhkam, Mari Must, Mart Mäger, Helmi Neetar, Salme Nigol, Ellen Niit, Vilja Oja, Valdek Pall, Eevi Ross, Aili Univere, Helmi Viires. Käsikirja ühtlustanud ja täiendanud Mari Must. Trükki toimetanud Helmi Neetar, Ellen Niit, Eevi Ross. Eesti Teaduste Akadeemia Eesti Keele Instituut. Tallinn: Eesti Keele Instituut.

Habicht jt 2011 = Külli Habicht, Pille Penjam, Külli Prillop. Sõnaliik kui rakenduslik ja lingvistiline probleem: sõnaliikide märgendamine vana kirjakeele korpuses. - Eesti Rakenduslingvistika Ühingu aastaraamat 7. Toim. Helle Metslang, Margit Langemets, Maria-Maren Sepper. Tallinn: Eesti Keele Sihtasutus, 19-41. http://dx.doi.org/10.5128/ERYa7.02.

Heine, Bernd, Tania Kuteva 2002. World Lexicon of Grammaticalization. Cambridge: Cambridge University Press. http://dx.doi.org/10.1017/ CBO9780511613463.

Hopper, Paul J., Elizabeth C. Traugott 2003. Grammaticalization. Second Edition. Cambridge: University Press. http://dx.doi.org/10.1017/ CBO9781139165525.

Lindström, Liina 2009. Ülevaade eesti murrete korpusest; http://www.murre. ut.ee/assets/EMK.PDF.

Lindström jt 2006 = Liina Lindström, Liisi Bakhoff, Mari-Liis Kalvik, Anneliis Klaus, Rutt Läänemets, Mari Mets, Ellen Niit, Karl Pajusalu, Pire Teras, Kristel Uiboaed, Ann Veismann, Eva Velsker. Sõnaliigituse küsimusi

9 Siin on esitatud vaid need lühendid, mis aastaraamatu lühendiloetelust puuduvad. 
eesti murrete korpuse põhjal. - Keele ehe. Pühendatud keeleteadlase Reet Kasiku 60. sünnipäevale. Toim. Ellen Niit. (= Tartu Ülikooli eesti keele õppetooli toimetised 30.) Tartu: Tartu Ülikooli eesti keele õppetool, $154-167$.

Lindström jt 2009 = Liina Lindström, Eva Velsker, Ellen Niit, Karl Pajusalu. Mees 'man', aeg 'time' and other frequent words in the Corpus of Estonian Dialects. - Kodukeel ja keele kodu. Home language and the home of a language. Pühendusteos Helmi Neetarile 75. sünnipäevaks 29. jaanuaril 2009. Toim. Marja Kallasmaa, Vilja Oja. (=Eesti Keele Instituudi toimetised 13.) Tallinn: Eesti Keele Sihtasutus, 91-129.

Pajusalu, Renate 2006. Death of a demonstrative: person and time. The case of Estonian too. - Linguistica Uralica XLII (4), 241-253.

Rannut, Lehte 1960. Ajamäärus eesti keeles (tähendusfunktsioonid). - Emakeele Seltsi aastaraamat VI (1960). Eesti NSV Teaduste Akadeemia Emakeele Selts. Tallinn: Eesti Riiklik Kirjastus, 71-112.

Velsker, Eva 2010. Leksikaliseerumine keelemuutuses. - Keel ja Kirjandus 7, 521-536.

VVS $=$ Ülle Viks 1992. Väike vormisõnastik II. Sõnastik ja lisad. Toim. Henno Rajandi. Eesti Teaduste Akadeemia, Keele ja Kirjanduse Instituut. Tallinn.

Wiedemann, Ferdinand Johann 2011. Eesti keele grammatika. Tõlk. Heli Laanekask, toim. Ellen Niit. Tallinn: Eesti Teaduste Akadeemia Emakeele Selts.

\section{Veebiandmebaasid}

http://www.murre.ut.ee/murdekorpus 


\title{
Aeg 'time' in Estonian dialects
}

\author{
Eva Velsker
}

The article focuses on the usage of the word aeg 'time' in Estonian dialects; the material comes from the Corpus of Estonian Dialects, the preparation of which is underway at the University of Tartu and the Institute of the Estonian Language. The word aeg 'time' is a high-frequency noun in the dialect corpus, whereas its usage reveals considerable variation. For the purpose of the present study the author collected 1899 forms of the word aeg; 1509 of them were used as time adverbials; 1256 expressed time of the action; the analysis focused on the latter. It appeared that the choice of the form depends, on the one hand, on the grammatical environment; it depends on whether the word is modified by a genitive or adjective attribute; on the other hand, different dialects employ different linguistic devices. The frequent combination with the pronominal extension see 'this' (too 'that'), which usually is in the adessive, could be regarded as an adverbialized form. Among other dialects, the combination of the adessive pronoun and the partitive aeg is a distinctive feature of the Vorru dialect. In the case of the adjective attribute, mostly the adessive form is used in all the dialects, and, thus, one is dealing with a clearly substantival use. Phrases with the genitive attribute reveal more variation - more western dialects show mostly the inessive, the insular dialects also the partitive; in the central dialect the nominative is common in such contexts. In other northern Estonian dialects the adessive is common. The Tartu dialect distinguishes an adpositional form, which is clearly a divergence from the case paradigm. However, in the Vorru dialect it is morphologically not possible to make a distinction between the adposition and the partitive. In constructions with the genitive attribute, the forms of the word aeg can often be interpreted as the adposition; however, the morphological preferences differ in different dialects. The interpretation as the adposition is supported by the fact that usually another case (the adessive) is used in phrases with an adjective attribute.

Keywords: Estonian dialects, variation, lexicalization, grammaticalization

Eva Velsker

eesti ja üldkeeleteaduse instituut

Tartu Ülikool

Jakobi 2-439

51014 Tartu

eva.velsker@ut.ee 